\title{
ФОРМУВАННЯ ПРОФЕСІЙНОЇ КОМПЕТЕНТНОСТІ СТУДЕНТІВ У ПРОЦЕСІ ВИВЧЕННЯ ЛОГІКИ
}

Козаченко Н. П. Формування професійної компетентності студентів у прочесі вивчення логіки.

У статті розглянуто співвідношення між професійною компетентністю та логічною культурою. Автор формулює основні характеристики логічної культури студентів та учнів у контексті компетентнісного підходу.

Ключові слова: професійна компетентність, логічна культура, рачіональність, ефективна діяльність, формалізаиія.

Козаченко Н. П. Формирование профессиональной компетентности студентов в процессе изучения логики.

В статье рассматривается соотношение между профессиональной компетентностью $и$ логической культурой. Автор формулирует основные характеристики логической культуры студентов и учащихся в контексте компетентностного подхода.

Ключевые слова: профессиональная компетентность, логическая культура, рациональность, эффективная деятельность, формализачия.

Kozachenko N. The formation of professional competence of students in the study of logic.

The article discusses the relation between professional competence and logical culture. The author formulates the main characteristics of logical culture of the students and pupils in the context of competence-based approach.

Key words: professional competence, logical culture, rationality, effectiveness, formalization.

Постановка проблеми. Інформаційне суспільство диктує нові стандарти освіти, які адекватно відображено в компетентнісному підході до навчання, що прийшов на зміну так званому «знаннєвому». Саме тому освіта нині спрямовується на підвищення професійної компетентності, формування пізнавальної самостійності. Випускник навчального закладу має володіти не тільки певним багажем знань, умінь та навичок, але й методами здобуття й опрацювання нової інформації. Необхідність оперувати значним обсягом інформації, знаходити і виокремлювати головне, потрібне, робити висновки i прогнози, передбачувати наслідки своєї діяльності складають невід'ємну частину професійної компетентності фахівця і водночас $є$ частиною його логічної культури.

Метою нашого дослідження постає розкриття зв'язку професійної компетентності з логічною культурою фахівця та визначення способів формування певних аспектів професійної компетентності в процесі навчання логіки.

Актуальність дослідження зумовлено двома чинниками. По-перше, наявність логічної культури є невід'ємною ознакою освіченої особистості і становить основу для формування ключових аспектів професійної компетентності. По-друге, введення в шкільні програми курсу логіки зумовлює необхідність підготовки відповідних фахівців, які б змогли не просто навчити дітей основним поняттям логіки, але й сформувати у них 
певний рівень абстрактного мислення та навички використання логічних прийомів у навчальній діяльності.

Різними аспектами компетентнісного підходу опікуються вітчизняні науковці Я. Кодлюк, О. Локшина, О. Овчарук, О. Пометун, О. Савченко та інші. Дослідженням особливостей формування професійної компетентності також займаються російські дослідники: В. Болотов, В. Краєвський, В. Серіков, А. Хуторський та інші, подібними питаннями опікуються й зарубіжні фахівці: А. Бермус, Дж. Равен, Р. Уайт, Е. Шорт та інші.

Проаналізувавши різні визначення професійної компетентності, можна дійти до висновку, що це неоднозначне поняття, яке варто визначати через сукупність його ознак. У якості найзагальнішого означення професійну компетентність будемо розглядати як спроможність результативно діяти, ефективно розв'язувати стандартні та проблемні ситуації, що виникають у професійній (педагогічній) діяльності [6, с. 94].

До основних ознак професійної компетентності можна віднести такі:

- здатність виконувати конкретні дії в певній галузі діяльності, яка поєднує в собі знання, навички, способи мислення і готовність нести відповідальність за свої вчинки (Дж. Равен);

- здатність об'єктивно оцінювати ситуацію й ефективно діяти в разі необхідності (А. Хуторський);

- здатність людини здійснювати складні поліфункціональні, поліпредметні, культуродоцільні види діяльності, ефективно розв'язуючи відповідні проблеми (О. Пометун);

- спроможність особистості сприймати та відповідати на індивідуальні й соціальні потреби (О. Овчарук).

До виявів професійної компетенції, зокрема, можна віднести i здатність до навчання і самоосвіти упродовж професійної діяльності.

Компетентнісний підхід передбачає такий зміст освіти, який «не зводиться до знаннєво-орієнтувального компонента, а передбачає цілісний досвід розв'язання життєвих проблем, виконання ключових (тобто тих, які стосуються багатьох соціальних царин) функцій, соціальних ролей, компетенцій» [1, с. 10]. Фактично, йдеться про «дві освіти»: перша «очевидна» - навчальна, підлягає обов'язковому засвоєнню й контролю; друга - «прихована освіта», включає ті досягнення та результати, що не обмежуються певним набором знань та умінь, але «сприяють формуванню компетентності, особистісного досвіду й інших показників освіченості» $[1, \mathrm{c}$. 10]. Саме до такої «прихованої» частини освіти належить логічна культура, формування якої найчастіше не є завданням окремого предмету, але неявно передбачається змістом всіх навчальних курсів.

Сформованість логічної культури можна більшою мірою визначити через наявність таких умінь:

- встановлювати істинність та обгрунтованість інформації, аналізувати iii структуру, встановлювати взаємозв'язки з раніше набутими знаннями, оцінювати ііі корисність та адекватність; 
- узгоджено формулювати (вербалізувати) набуті знання, визначати їх логічну структуру, зв'язки та закономірності;

- формулювати та обгрунтовувати висновки з отриманої інформації, будувати коректне доведення власної тези, визначати помилки в обгрунтуваннях, спростовувати хибні тези;

- виявляти у будь-якому тексті міркування, їх вихідні положення та висновки, обгрунтовувати чи спростовувати їх, міркувати згідно з законами логіки, знаходити помилки, пов'язані з порушенням законів логіки;

- правильно оперувати поняттями, здійснювати підведення під поняття, формулювати означення поняття, аналізувати професійну термінологію, здійснювати правильний поділ понять, класифікувати, узагальнювати та обмежувати поняття;

- формувати цілісну систему набутих знань як абстрактну конструкцію взаємопов'язаних умовиводів, оцінювати інформацію, що надходить, згідно 3 наявною системою знань, адекватно «вписувати» нові знання до неї;

- вміння визначати формальні характеристики досліджуваного явища, переносити відомі характеристики на нові об'єкти дослідження [3, с. 8].

Відповідність компонентів логічної культури ознакам професійної компетенції $\epsilon$ незаперечною, але часто неочевидною, тому потребує додаткового докладного аналізу.

1. Можливість ефективно діяти в певній галузі забезпечується не тільки наявністю знань і досвіду, але й умінням вербалізувати, описати $\mathrm{i}$ проаналізувати завдання. У свою чергу, наведені процедури спонукають до вибору ефективного методу виконання завдання. Вибір методу розв'язання грунтується на можливості адекватно зробити висновки з певного матеріалу, передбачити наслідки реалізації обраного варіанту, що є безпосереднім результатом сформованості логічної культури.

2. Здатність об'єктивно оцінювати ситуацію передбачає поміркований, незаангажований погляд, що у повній мірі реалізується формально-логічним підходом. Визначення логічної форми, істинності та обгрунтованості суджень, що описують дану ситуацію, встановлення відношень та виведення висновків 3 них дають змогу побачити ситуацію загалом, незалежно від емоційного компоненту сприйняття. Раціональний підхід у поєднанні 3 ціннісно-вольовим дозволить фахівцю оцінити важливість ситуації, підібрати оптимальні методи її розв'язання. Крім того, може статися так, що в результаті логічного аналізу, ситуація виявиться надуманою або такою, що не потребує розв'язання.

3. Здатність людини здійснювати складні поліфункціональні дії безпосередньо випливає з уміння встановлювати формальні характеристики розглядуваного явища, переносити властивості вже відомих об'єктів та процесів на нові, подібні до них за формою та структурою. Вміння діяти за аналогією також $є$ компонентом логічної культури. Крім того, поліфункціональність фахівця є наслідком сформованого досить високого рівня абстрактного мислення, що дозволяе розглянути ситуацію загалом, оцінити іii 
характеристики як компоненти більш складної системи, розглянути проблему як частину складного комплексу взаємопов'язаних елементів.

4. Сприйняття та відповідь на актуальні індивідуальні та соціальні потреби передбачає наявність цілісного розуміння суспільства як системи, власної особистості як його підсистеми, що має свою внутрішню структуру. Зазвичай, саме цей аспект компетентності найменш раціоналізований і більшою мірою залежить від психологічних характеристик особистості. Проте, вміння, передбачені наявністю логічної культури, виконують значну оптимізуючу функцію і у цьому випадку. Передовсім, це вищезазначені вміння аналізувати і робити висновки з наявної інформації, що допомагають оцінити нагальність ситуації та необхідність прийняття рішення. По-друге, це можливість раціонально оцінити свої та суспільні потреби, пов'язати їх як елементи структури, передбачити наслідки своєї поведінки тощо.

5. Здатність до навчання та самоосвіти безпосередньо пов'язана з рівнем логічної культури. Логічні знання є основою навчальної наукової діяльності, передбачають сформованість уявлень про основні прийоми i методи раціонального пізнання та оперування абстрактними об'єктами, оформлення результатів та підведення підсумків пізнавальної діяльності.

Установлений зв'язок між професійною компетентністю та логічною культурою передбачає формулювання певних завдань і методів розвитку логічної культури майбутнього фахівця у системі вищої освіти й має особливе значення у навчанні студентів - майбутніх педагогів.

Упровадження логічних знань у педагогічній діяльності має велике значення для формування критичного та раціонального мислення учнів. Робота педагога полягає не тільки у передачі знань, а й у виробленні в учнів навичок самостійного оволодіння знаннями та критичного аналізу інформації. Вивчення курсу логіки передбачає подальше застосовування отриманих знань у професійній педагогічній діяльності, вчитель має вміти сам і навчити учнів:

- раціонально формулювати власну думку, встановлювати логічні зв’язки між частинами висловлювання, тексту, міркування.

- критично оцінювати інформацію, переглядати іï на предмет неузгодженості, виявляти та ліквідувати виявлені суперечності;

- коректно будувати аргументацію власної думки, спростовувати хибні тези та знаходити помилки в аргументаціях інших;

- правильно формулювати означення, встановлювати суттєві та несуттєві ознаки явищ та предметів, підводити під поняття, виконувати інші операції над поняттями;

- пояснювати властивості явища, коректно виводячи їх з означень та наявної інформації, проводити аналогії, робити адекватні прогнози та припущення.

Задля досягнення поставлених цілей, курс логіки, що традиційно викладається у Криворізькому національному університеті, передбачає перелік тем, до яких входить встановлення логічної форми та логічної модальності висловлювань, логічних зв'язків між висловлюваннями, перевірка правильності міркувань, виведення висновків із посилок, логічний аналіз понять та висловлювань тощо. 
Вивчення кожної теми завершується виконанням відповідного завдання, що дає змогу студенту об'єктивно оцінити рівень засвоєння матеріалу. Завдання зорієнтовано на застосування прийомів логічного аналізу до художнього та наукового тексту, формулювання та перевірку правильності міркувань, обгрунтування чи спростування тези. Особливу увагу приділено методиці визначення понять, адже володіння відповідною термінологією основне підгрунтя для подальшого розуміння матеріалу. В результаті вивчення курсу логіки студент має засвоїти основи формального підходу, навчитися робити висновки 3 даного матеріалу та усвідомити зв'язок між формами раціонального пізнання і принципи функціонування теоретичного знання. Результатом засвоєння теоретичного матеріалу та виконання практичних завдань має стати свідоме та цілеспрямоване застосування логічних методів у професійній діяльності та в повсякденному спілкуванні.

Можна констатувати, що університетський курс логіки є усталеним і в якому наявна значна кількість методичних доробок, які щоправда не утворюють цілісної системи (див. [2], [3], [7]). Однак широке поле для подальших досліджень відкривається у розробленні шкільної методики викладання логіки, як в молодших, так і в старших класах спеціалізованих навчальних закладів. Основна проблема полягає у відсутності педагогічних доробок царини фахівців 3 логіки, натомість методика логіки найчастіше зводиться до методики математики, або й взагалі до загальної методики. Основною метою створення цілісної методики $є$ недопущення формального (у негативному смислі) підходу до викладання логіки у школі, що виявляється у відсутності уніфікованих якісних шкільних програм з цього предмета, фрагментарному наданні учням розрізнених аспектів логічних знань, викладання матеріалу за підручниками, написаними неспеціалістами, оперування застарілим матеріалом, відірваності вітчизняного курсу логіки від світового досвіду та його практичного застосування.

\section{Література}

1. Болотов В. А. Компетентностная модель: от идеи к образовательной програмне / В. А. Болотов, В. В. Сериков // Педагогика. - 2003. - № 10. - С. 8-14.

2. Войшвилло Е. К. Логика как часть теории познания и научной методологии. Фундаментальный курс / Е. К. Войшвилло, М. Г. Дегтярев. - М. : Наука, 1994. - Кн.1 - 312с.

3. Козаченко Н. Логіка: [навч. посіб.] / Н. Козаченко. - Кривий Ріг: КДПУ, 2011. - 135с.

4. Овчарук О. В. Розвиток компетентнісного підходу: стратегічні орієнтири міжнародної спільноти / О.В. Овчарук // Компетентнісний підхід у сучасній освіті: світовий досвід та українські перспективи. - К. : “К.І.С.”, 2004. - 112с.

5. Пометун О. І. Теорія та практика послідовної реалізації компетентнісного підходу в досвіді зарубіжних країн / О. І. Пометун // Компетентнісний підхід у сучасній освіті: світовий досвід та українські перспективи. - К. : “К.І.С.”, 2004. - 112с.

6. Скворцова С. О. Професійна компетентність вчителя: зміст поняття / С. О. Скворцова // Наука і освіта. - 2009. - №4. - С. 93-96.

7. Хоменко І. Логіка: теорія та практика / I. Хоменко. - К. : Центр учбової літератури, 2010. $-400 \mathrm{c}$.

Стаття надійшла до редакції 16.04.2012 p. 